\title{
Origin-dependence of variation in seed morphology, mineral composition and germination percentage in Gynandropsis gynandra (L.) Briq. accessions from Africa and Asia
}

\author{
Jelila S. Blalogoe ${ }^{1,2}$, Alfred O. Odindo ${ }^{3}$, E. O. Dêêdi Sogbohossou ${ }^{1,4}$, Julia Sibiya ${ }^{2}$ and Enoch G. Achigan-Dako ${ }^{1 *}$
}

\begin{abstract}
Background: Spider plant [Gynandropsis gynandra (L.) Briq.], an economically promising African leafy vegetable, characterized for leaf yield components and nutritive quality, exhibits poor seed germination that hinders a wider expansion of the crop in urban and periurban horticultural systems. So far, there is little information pertaining to seed morphological traits and mineral elements content that may be associated with higher seed germination. This research investigated the hypothesis that spider plants from different geographical areas exhibited differences in seed mineral composition, morphological traits, and germination capacity. To this end, twenty-nine accessions of Gynandropsis gynandra from West and East-Southern Africa, and Asia were screened for variation in seed size (area, perimeter, length, width), 10-seed weight, mean germination time, germination percentage and mineral content variations. The scanning electron microscopy (SEM), light microscopy and energy dispersive spectroscopy (EDS) solution were used to study seed morphology and mineral composition.
\end{abstract}

Results: We show for the first time the external and internal structure of the seeds of Gynandropsis gynandra and measured eight mineral elements, including carbon (C), oxygen (O), magnesium (Mg), aluminium (Al), phosphorus $(\mathrm{P})$, sulphur $(\mathrm{S})$, potassium $(\mathrm{K})$ and calcium $(\mathrm{Ca})$. The accessions differed significantly $(p<0.001)$ with respect to seed size (area, perimeter, length, width), 10-seed weight, mean germination time and germination percentage. The hierarchical cluster analysis based on fourteen variables grouped the accessions into three distinct clusters, partially dependent on their geographical origin. Asian accessions exhibited smaller seeds and recorded higher values in terms of germination percentage. West African accessions had bigger seeds but with lower germination percentage. Variation in minerals such as potassium, carbon, and calcium content showed different patterns according to geographical origins.

(Continued on next page)

\footnotetext{
* Correspondence: e.adako@gmail.com

'Laboratory of Genetics, Horticulture and Seed Science, Faculty of

Agronomic Sciences, University of Abomey-Calavi, BP 526 Abomey-Calavi,

Republic of Benin

Full list of author information is available at the end of the article
}

C C The Author(s). 2020 Open Access This article is licensed under a Creative Commons Attribution 4.0 International License, which permits use, sharing, adaptation, distribution and reproduction in any medium or format, as long as you give appropriate credit to the original author(s) and the source, provide a link to the Creative Commons licence, and indicate if changes were made. The images or other third party material in this article are included in the article's Creative Commons licence, unless indicated otherwise in a credit line to the material. If material is not included in the article's Creative Commons licence and your intended use is not permitted by statutory regulation or exceeds the permitted use, you will need to obtain permission directly from the copyright holder. To view a copy of this licence, visit http://creativecommons.org/licenses/by/4.0/. The Creative Commons Public Domain Dedication waiver (http://creativecommons.org/publicdomain/zero/1.0/) applies to the data made available in this article, unless otherwise stated in a credit line to the data. 
(Continued from previous page)

Conclusion: Smaller seeds in G. gynandra exhibited better germination capacity. The Asian germplasm is a potential source of cultivars with a higher germination percentage for improving seed quality in the species.

Keywords: Characterization, Cleome gynandra, Germination, Mineral element contents, Seed morphology, Seed viability, Scanning Electron microscope

\section{Background}

Successful breeding programmes and crop production require good quality seeds for increased yield to ensure food and nutritional security for the growing populations $[1,2]$. Seed germination and seedling emergence are critical phases in the development of plants and this implies that seed vigour is an important trait for the selection of important crop cultivars $[3,4]$. The capacity of a seed to germinate quickly and competitively depends on the genetic and physiological constitution of the seed $[5,6]$. In addition, seed size at maturity is an important physical indicator of seed quality which can affect vegetative growth and is frequently related to yield [1]. It is commonly known that because of the larger store of carbohydrate in the seed endosperm or cotyledons, seedlings from larger seeds have a better start in life and better field performance than smaller seeds [7]. Morphological measurements including length, width, area, perimeter and weight are important parameters for determining the size and shape of seeds [8]. Seed shape and size can influence water imbibition, seed moisture content and consequently seed germination and quality [9-11]. For instance, Gholami and al [12] observed an increase in germination as well as a greater speed of germination in larger seeds compared with small seeds in the common bean (Phaseolus vulgaris L.). It was shown that larger seeds of Amaranthus spp. possessed higher physiological quality [13] than smaller seeds.

In addition, seed mineral composition also determines plant establishment and growth. Seeds contain several macronutrients like phosphorus $(\mathrm{P})$ and micronutrients, including Zinc (Zn), Boron (B), Molybdenum (Mo), Selenium $(\mathrm{Se})$, copper $(\mathrm{Cu})$, cobalt $(\mathrm{Co})$ which are important for seed germination, seedling emergence and seed vigour $[3,14,15]$. For instance, it was observed that annual pasture legume yields are positively correlated with phosphorus concentration in seeds [16].

Breeding for grain yield, seed size, seed mineral content and seed vigour requires a fundamental assessment of the seed metrics, mineral composition, and germination capacity. In Gynandropsis gynandra (Cleomaceae), low seed germination was reported by growers as a major constraint limiting the species' productivity [17]. Although Gynandropsis gynandra is a leafy vegetable with high nutritional values [18-20], the leaf yield is not only dependent on the leaf components but also on the seed quality and mineral composition. Characterization studies [21-23] focused on traits including leaf number, number of branches, stem colour and leaf area. Variation in seed morphology has been rarely documented although a large genetic diversity among accessions were frequently reported for morphological traits [19, 20, 23, 24], leaf mineral composition [19] and secondary metabolites [20]. However, variation in the quality and mineral composition of the seeds of G. gynandra have not yet been documented. Information on the variability in morphological traits and mineral composition among accessions from different regions could be useful to improve seed quality and develop a strong breeding agenda.

The objectives of this study are therefore (i) to screen seeds of G. gynandra from different geographical regions for their mineral composition and (ii) to assess seed phenotypic diversity and variation in mineral content among accessions and in relation to seed germination. The study hypothesized that mineral composition and seed size in Gynandropsis gynandra vary among accessions from different geographical regions, and large seeds with high phosphorus content germinate better than small seeds with low phosphorus content.

\section{Results}

External and internal structures of Gynandropsis gynandra seeds

Gynandropsis gynandra seeds are generally brown or black in colour (Fig. $1 \mathrm{a}$ and b). The seeds are round or fairly round depending on the accession and pointed at the apical region where the radicle is located. The hilum is located at the center of the seed. The surface of the seed is rough with small rounded or ocellated depressions and ridges on the whole surface of the seed. Spider plant accessions split into two major seed types (Table 1) based on the seed surface. The first one consisted of thirteen accessions with slightly rough seed surface (Fig. $1 \mathrm{c}$ and $\mathrm{d}$ ) and the second consisted of sixteen accessions with very rough seed surface (Fig. 1 e and f). Illustrations of cross and longitudinal sections, based on observations from the Scanning Electron Microscopy (SEM) showed the embryo and the seed coat (Fig. 2) but not the overall organization of the seed. The longitudinal section of seeds observed under a light microscope revealed the overall organization of the spider plant seeds (Fig. 3). The embryo consisted of a hypocotyl-radicle axis and 

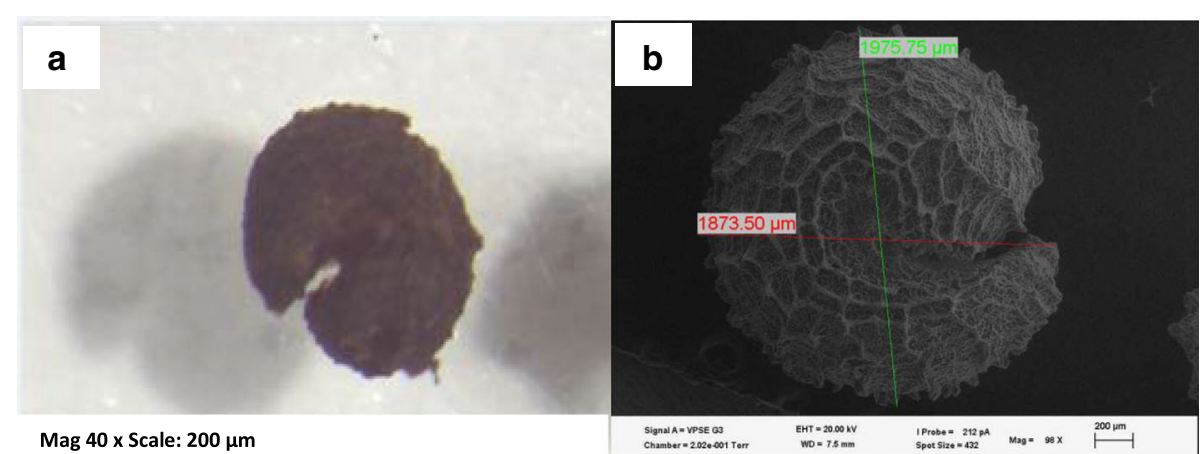

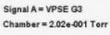

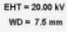

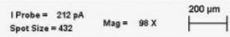
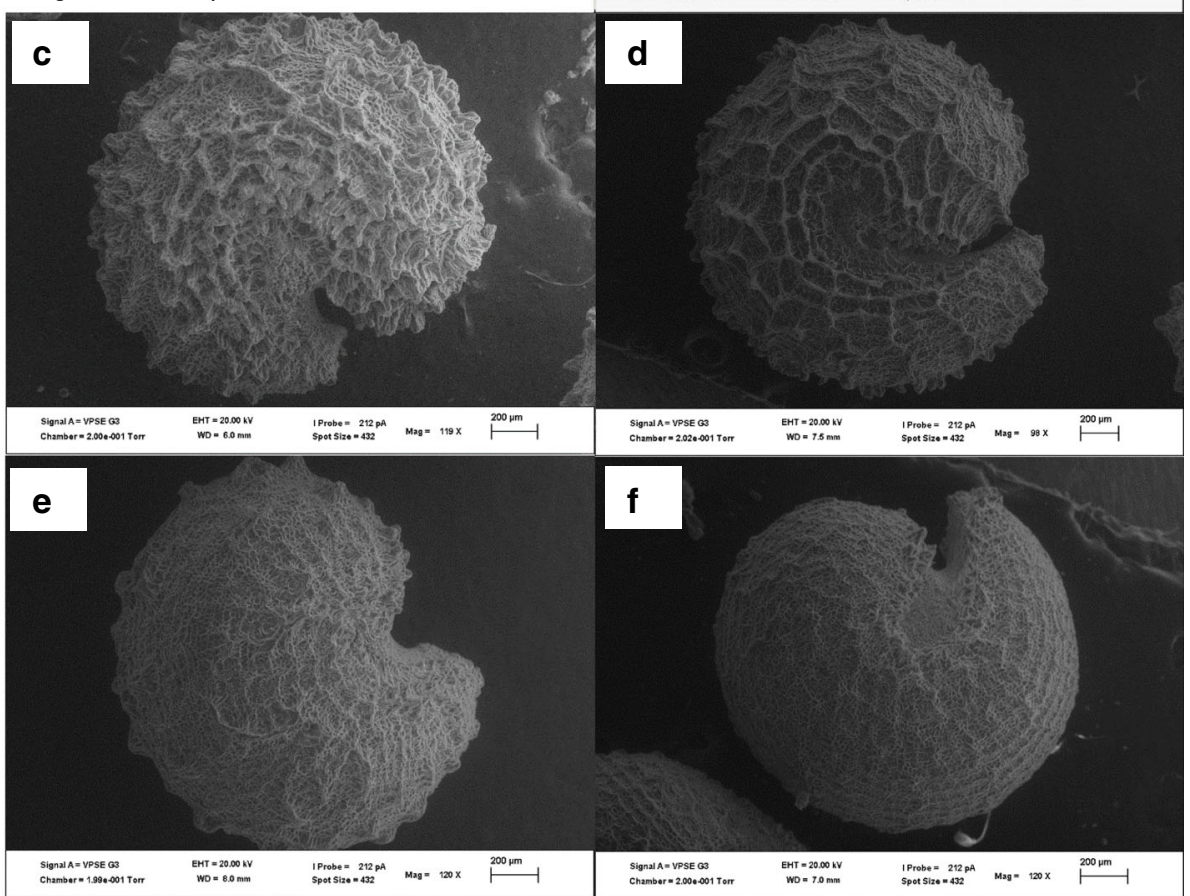

Fig. 1 SEM of Gynandropsis gynandra accessions. a: Light microscopy showing seed colour; $\mathbf{b}$ : Seed image analysis (in green the seed length and in red the seed width); c: Fairly round shape with very rough seed surface; $\mathbf{d}$ : Round shape with very rough seed surface; e: Fairly round shape with slightly rough seed surface $\mathbf{f}$ : Round shape with slightly rough seed surface

two cotyledons and the endosperm in the micropylar region.

\section{Variation in seeds quantitative morphological traits}

The analysis of variance (ANOVA) showed highly significant differences among the spider plant accessions for morphological traits such as seed area, seed perimeter, seed length, seed width, and 10-seed weight (Supplementary file 1). The seed area ranged from $95.42 \pm 4.05$ to $218.81 \pm 3.55 \mathrm{~mm}^{2}$ with an average of
$149.42 \pm 33.63 \mathrm{~mm}^{2}$. High values were obtained for accessions ODS-15-044, ODS-15-115, TOT6439, ODS-15020, ODS-15-100, ODS-15-013, ODS-15-021 and BAR1807B. A lower value was obtained for accession TOT3527. The seed perimeter varied between $3.87 \pm$ 0.05 and $6.19 \pm 0.59 \mathrm{~mm}$ with an average of $4.90 \mathrm{~mm}$. Higher values were obtained for ODS-15-020, TOT8887, ODS-15-044, ODS-15-115, ELG19/07A, BAR 1807B, ODS-15-013, ODS-15-100, ODS-15-121, while a lower value was obtained for accession TOT3527. The seed

Table 1 Distribution of Gynandropsis gynandra accessions based of seed surface roughness

\begin{tabular}{|c|c|}
\hline Seed surface roughness & Accessions name \\
\hline $\begin{array}{l}\text { Slightly rough seed } \\
\text { surface }\end{array}$ & $\begin{array}{l}\text { ODS-15-020, ODS-15-061, ODS-15-100, HBY 2307/b, KSI, TOT7196, TOT6439, ODS-15-121, TOT7200SC, TOT8931, TOT1048, } \\
\text { ELG1907A, BAR1807B }\end{array}$ \\
\hline $\begin{array}{l}\text { Very rough seed } \\
\text { surface }\end{array}$ & $\begin{array}{l}\text { ODS-15-115, TOT4976, TOT7486, ODS-15-019, TOT7505, KF 07, TOT5799, ODS-15-013, TOT8886, TOT7198, ODS-15-045, } \\
\text { TOT3536 }\end{array}$ \\
\hline
\end{tabular}




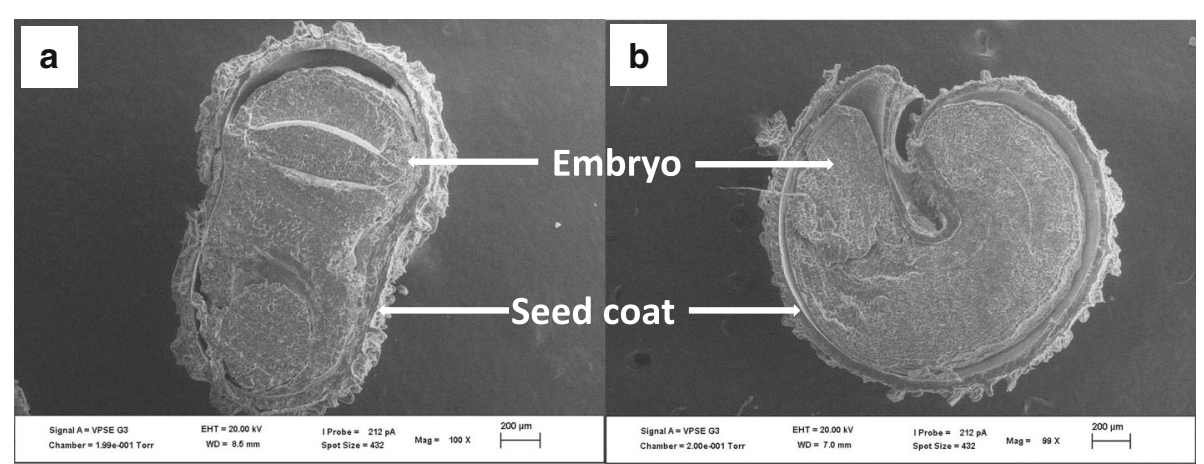

Fig. 2 Gynandropsis gynandra internal seed morphology under Scanning Electron Microscopy. a: Seed cross section b: Seed longitudinal section

width ranged between $0.93 \pm 0.05$ and $1.74 \pm 0.02 \mathrm{~mm}$ with an average of $1.29 \pm 0.17 \mathrm{~mm}$. Higher values were obtained in accessions ODS-15-044, ODS-15-115, TOT6439, ODS-15-013, ODS-15-020, ODS-15-100 and a lower value in the accession TOT3527. The seed length ranged from $1.19 \pm 0.05$ to $1.69 \pm 0.01 \mathrm{~mm}$ with an average of $1.43 \pm 0.15 \mathrm{~mm}$. The accessions BAR1807B, ODS-15-044, ODS-15-020, ODS-15-115, ODS-15-121, TOT6439, TOT8887, ODS-15-100, ODS-15-15-019 showed higher values while a lower value was obtained for the accession TOT7200SC. The 10-seed weight of spider plant accessions ranged from $6.33 \pm 0.58$ to $17.10 \pm 0.85 \mathrm{mg}$ with an average of $10.44 \pm 3.13 \mathrm{mg}$. The accessions with higher seed weight were ODS-15-121, ODS-15-111, TOT6439 and KSI2407A. Accession TOT7198 showed a lower seed weight. A significant difference with geographical origin was also observed for all the morphological traits (Fig. 4). In general, Asian accessions showed smaller seeds while West Africa's accessions showed bigger seeds values.

\section{Mineral composition of Gynandropsis gynandra seeds}

The screening of G. gynandra seeds by the Energy Dispersive Spectroscopy Solution showed a total of eight mineral elements, including carbon $(\mathrm{C})$, oxygen $(\mathrm{O})$, magnesium $(\mathrm{Mg})$, aluminium $(\mathrm{Al})$, phosphorus $(\mathrm{P})$, sulphur (S), potassium $(\mathrm{K})$ and calcium $(\mathrm{Ca})$. Highly significant $(p<0.001)$ differences were observed among accessions with respect to all mineral elements, except for aluminium (Al) (Additional file 1). The coefficient of variation was relatively high $(>20 \%)$ for magnesium, phosphorus, sulphur, potassium and calcium. The carbon content in the seeds ranged from $55.92 \pm 0.42 \mathrm{~g} /$ $100 \mathrm{~g}$ to $62.82 \pm 2.04 \mathrm{~g} / 100 \mathrm{~g}$ with an average of $58.50 \pm$ $1.64 \mathrm{~g} / 100 \mathrm{~g}$ while oxygen content ranged between $33.39 \pm 1.69 \mathrm{~g} / 100 \mathrm{~g}$ and $40.11 \pm 0.71 \mathrm{~g} / 100 \mathrm{~g}$ with an average of $38.04 \pm 1.48 \mathrm{~g} / 100 \mathrm{~g}$ (Additional file 1). The accessions TOT8887, BAR1807B, TOT6439 and TOT8887 showed higher carbon content while accessions ODS-15-013 and ODS-15-061 showed higher value for oxygen. Moreover, lower value for carbon was observed in the accession ODS- 15- 053 while accession TOT8887 showed the lowest oxygen value. The magnesium content of spider plant seeds ranged from $0.11 \pm$ $0.70 \mathrm{~g} / 100 \mathrm{~g}$ to $0.56 \pm 0.01 \mathrm{~g} / 100 \mathrm{~g}$ with an average value of $0.30 \pm 0.10 \mathrm{~g} / 100 \mathrm{~g}$ while the aluminium content ranged from $0.01 \pm 0.02 \mathrm{~g} / 100 \mathrm{~g}$ to $0.70 \pm 0.71 \mathrm{~g} /$ $100 \mathrm{~g}$ with an average of $0.20 \pm 0.18 \mathrm{~g} / 100 \mathrm{~g}$. A higher

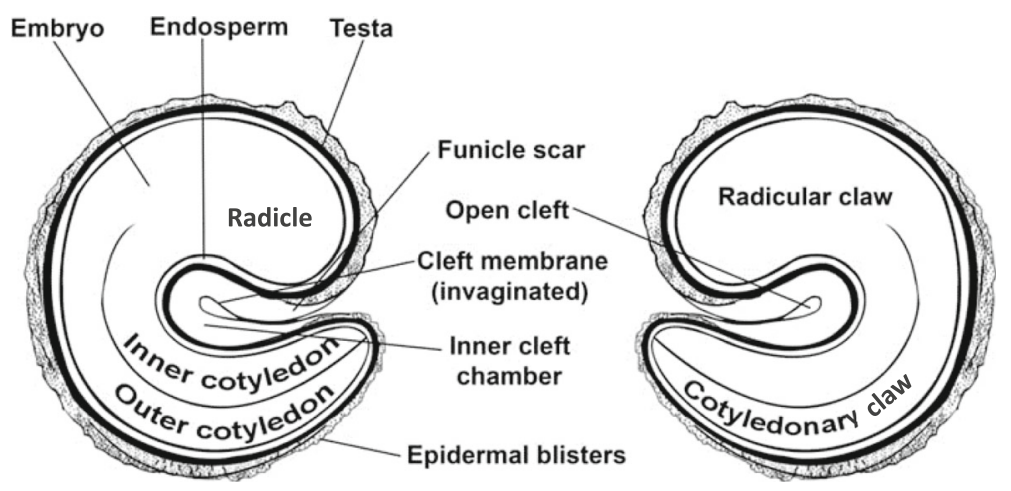

Fig. 3 Illustration of Gynandropsis gynandra seed in longitudinal section as viewed in light microscope: adapted from Iltis et al. [25] 


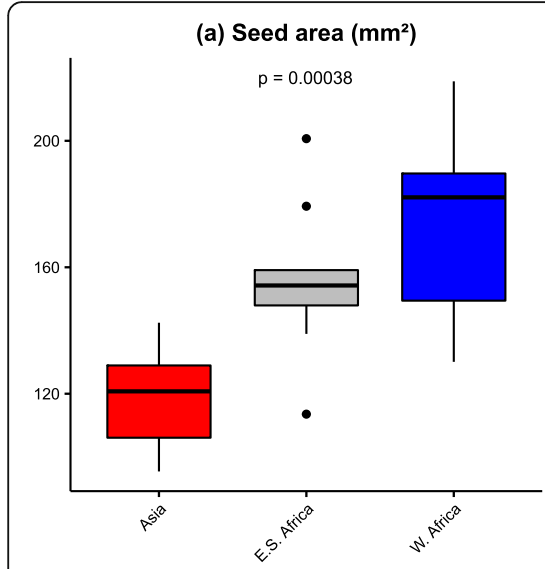

(b) Seed perimeter $(\mathrm{mm})$

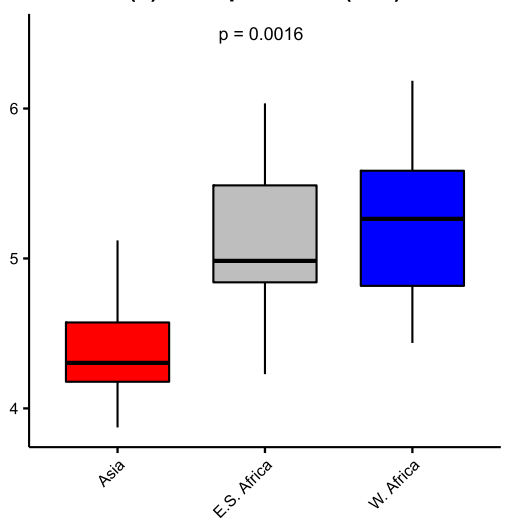

(e) 10-seed weight (mg)

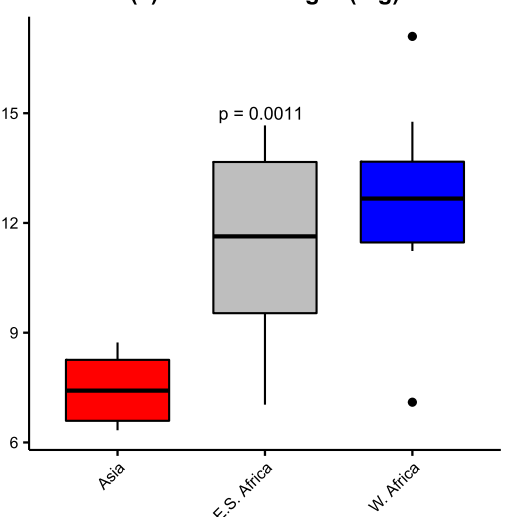

(c) Seed width $(\mathrm{mm})$

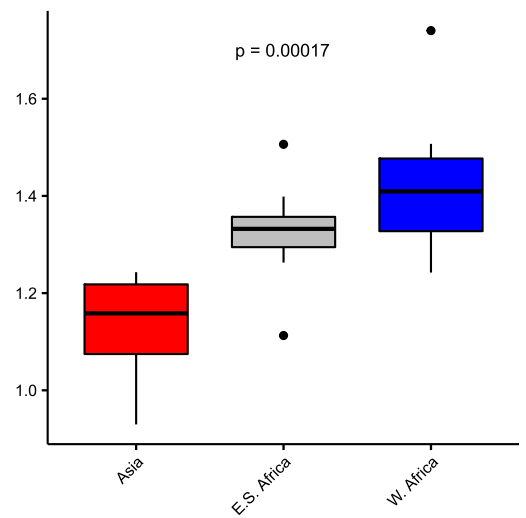

(d) Seed length ( $\mathrm{mm})$

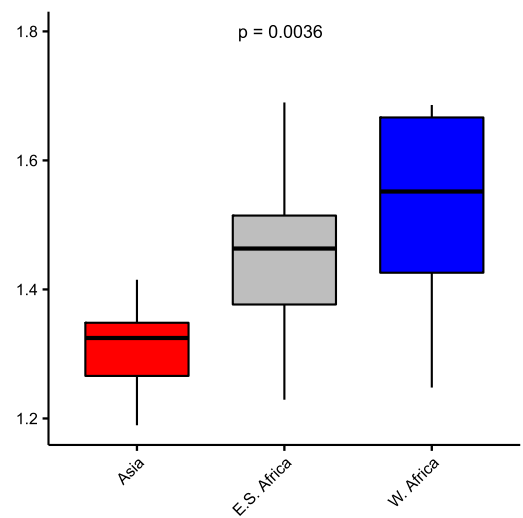

Fig. 4 Boxplot showing the variation in seeds morphological descriptors among Asian ( $n=10)$, East-Southern African ( $n=9)$ and West African $(n=10)$ accessions of Gynandropsis gynandra

value for magnesium was recorded for the accession ODS-15-053 while aluminium was higher for accession TOT8887. Phosphorus and sulphur content in the accessions ranged from $0.15 \pm 0.07 \mathrm{~g} / 100 \mathrm{~g}$ to $0.59 \pm 0.13 \mathrm{~g} /$ $100 \mathrm{~g}$ and from $0.33 \pm 0.10 \mathrm{~g} / 100 \mathrm{~g}$ to $1.17 \pm 01.4 \mathrm{~g} /$ $100 \mathrm{~g}$ with an average of $0.30 \pm 0.11 \mathrm{~g} / 100 \mathrm{~g}$ and $0.69 \pm$ $0.17 \mathrm{~g} / 100 \mathrm{~g}$ respectively. Higher phosphorus and sulphur values were both recorded for the accession ODS-15-053. Potassium content in Spider plant seed ranged from $0.08 \pm 0.05 \mathrm{~g} / 100 \mathrm{~g}$ to $2.58 \pm 1.25 \mathrm{~g} / 100 \mathrm{~g}$ while the calcium content ranged from $0.42 \pm 0.20$ to $1.79 \pm 0.24 \mathrm{~g} / 100 \mathrm{~g}$ with an average of $1.05 \pm 0.67 \mathrm{~g} /$ $100 \mathrm{~g}$ for potassium and $0.92 \pm 0.35 \mathrm{~g} / 100 \mathrm{~g}$ for calcium. Accession ODS-15-019, showed higher potassium content, while ELG 1907A showed higher calcium content.

Geographical origin affected the variation of mineral elements such as carbon, potassium and calcium (Fig. 5). For instance, accessions from West Africa contained a higher amount of potassium $(p=0.0052)$ compared with other regions. Accessions from Asia were richer in carbon and accessions from East-southern Africa exhibited higher calcium content.

\section{Variation in seed germination}

Prior seed viability test with 2,3,5-triphenyltetrazolium chloride on selected accessions from various origins revealed high viability percentage in Gynandropsis gynandra accessions. Viability percentages were $80 \%$ in TOT8887, 82.5\% in ELG1907A, 92.5\% in ODS-15-020, and $95 \%$ in TOT5799SC. Generalized linear model (GLM) analysis of the mean germination time and the percentage germination in spider plant showed highly significant differences $(p<0.001)$ among accessions (Supplementary file 1). The mean germination times ranged from four to five days with most accessions geminated within four days. Seed germination percentages after seven days varied from $24.24 \pm 10.50$ to $100 \%$. Five Asian accessions obtained $100 \%$ germination including TOT1048, TOT3527, TOT6439, TOT7198 and TOT7505. Lower germination percentages were observed from the East African accession KF07 (24.24 \pm $10.50 \%)$. The coefficient of variation was high for the germination percentage $(\mathrm{cv}=43.57 \%)$, which was indicative of implied diversity among the accessions used in this study. Moreover, the percentage of germination 


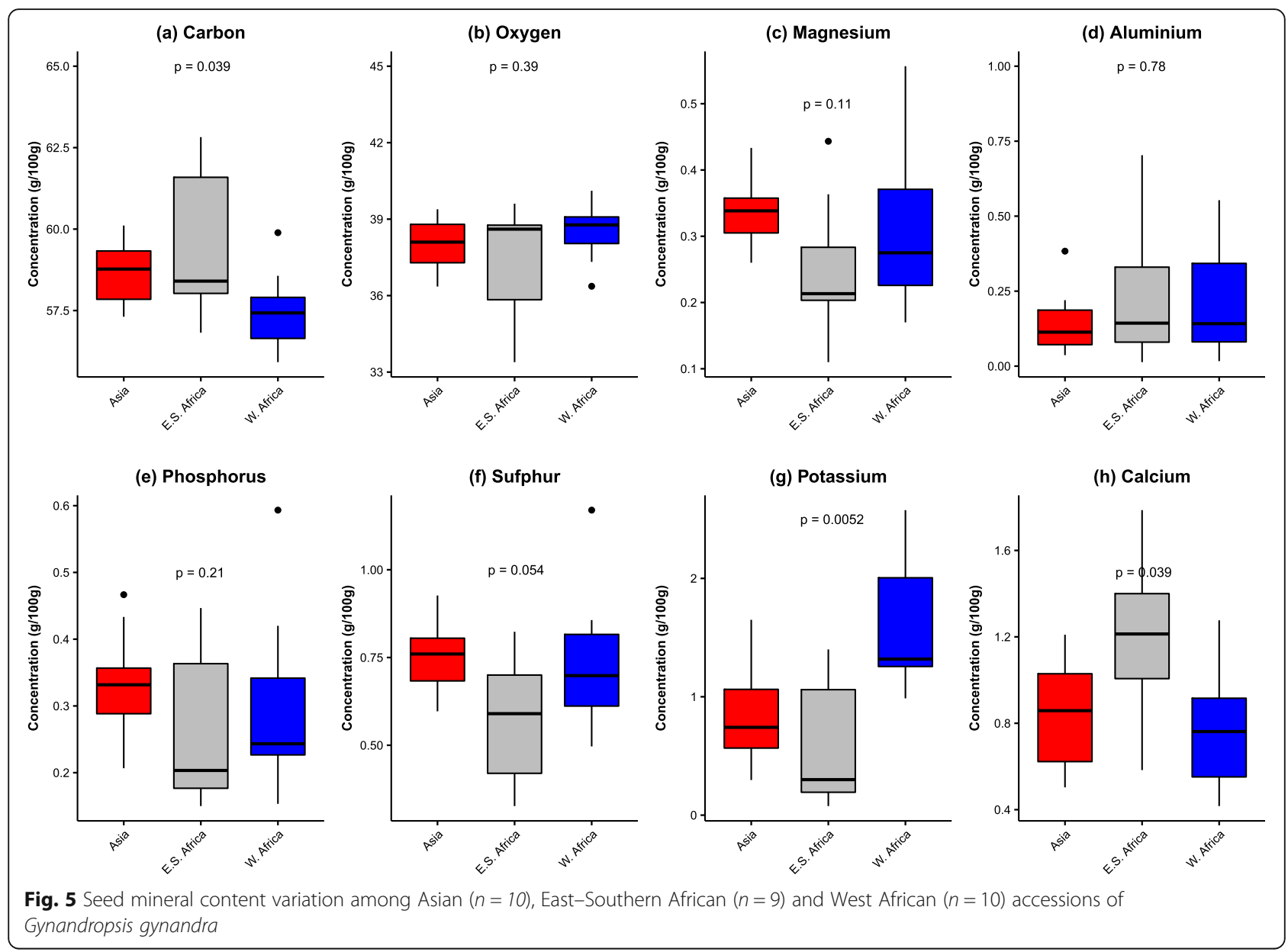

varied with geographical origin (Fig. 6). Asian accessions germinated better than accessions from other regions. The lowest germination percentage observed in Asian genotypes was $80 \%$ in this study.

\section{Correlation among seed traits, germination parameters and mineral composition}

The Pearson correlation analysis among germination percentage, mean germination time, morphological traits and mineral element contents of spider plant revealed highly significant, moderate, and negative correlations between seed area $(r=-0.52)$, seed perimeter $(r=-$ $0.58)$, seed length $(r=-0.53)$ and 10 -seed weight $(r=-$ $0.58)$, seed width $(r=-0.45)$ with magnesium content (Table 2). Moderate and negative correlations were observed between 10-seed weight $(r=-0.53)$, mean germination time $(r=-0.49)$ and sulphur content (Table 2). Likewise, significant moderate and negative correlations were also detected between 10-seed weight $(r=-0.52)$, seed area $(r=-0.47)$, seed width $(r=-0.45)$, mean germination time $(r=-0.44)$ and phosphorus content. A significant, low and negative correlation was observed between phosphorus content and seed perimeter $(\mathrm{r}=-$
0.37). In contrast, a significant moderate and positive correlation was observed between calcium content and 10 -seed weight $(r=0.47)$.

\section{Differentiation among G. gynandra accessions based on} principal components and hierarchical cluster analyses The principal components analysis using morphological traits, germination percentage, mean germination time and mineral content of spider plant seeds revealed that the three first components explained $69.25 \%$ of the total variation (Fig. 7). The first principal component axis (Dimension 1) explained $37.66 \%$ of variation and was highly correlated with magnesium, phosphorus, calcium, seed area, seed perimeter, seed width, seed length and seed weight. The second principal component axis (Dimension 2) explained $18.73 \%$ of the variation and was highly correlated with carbon, oxygen, and potassium content, mean germination time and germination percentage. The third principal component axis (Dimension 3) explained $13.14 \%$ and was highly correlated with aluminium and sulphur content (Table 3).

The Principal Components Analysis (PCA) grouped the 29 spider plants accessions into three major clusters 
(a) Mean germination time

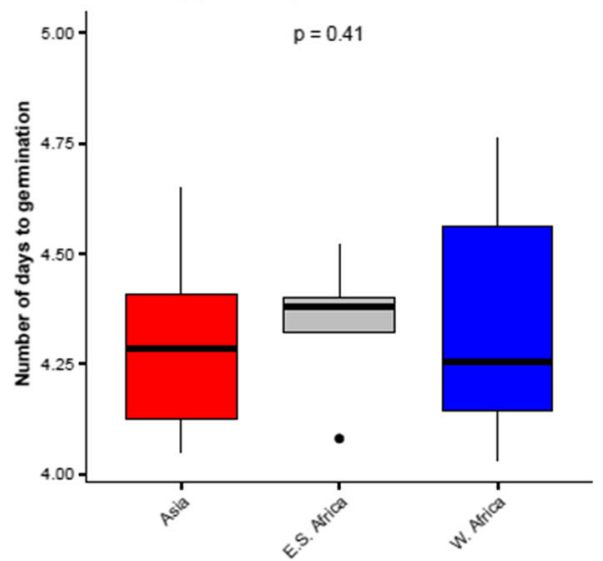

(b) Germination percentage

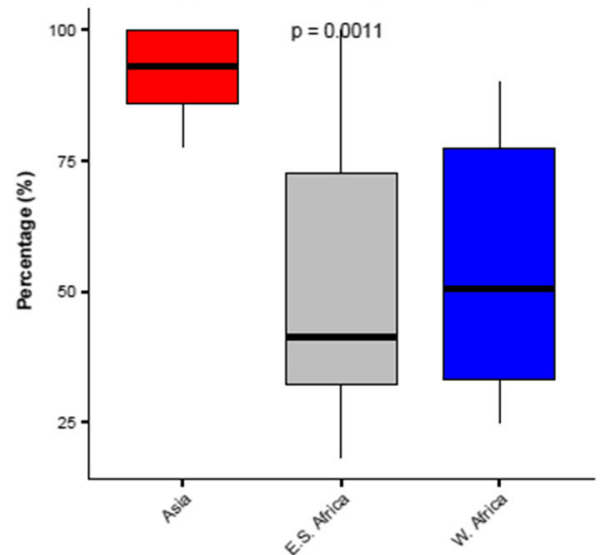

Fig. 6 Variation in (a) mean germination time and (b) germination percentage among Asian $(n=10)$, East-Southern African $(n=9)$ and West African $(n=10)$ accessions of Gynandropsis gynandra

(Fig. 7). Cluster 1 were highly separated from Cluster 2 and 3 (overall ANOSIM $\mathrm{R}=0.5$, Table 4) and discriminated by morphological traits (seed area, seed length, seed perimeter, 10-seed weight and seed width), mean germination time and mineral content (magnesium, phosphorus, sulphur, calcium, carbon, oxygen, and potassium).

Based on the PCA results, Cluster 1 was composed of $55.17 \%$ of spider plant accessions (Table 5). Seeds of those accessions were characterized by higher magnesium $(0.36 \pm 0.07 \mathrm{~g} / 100 \mathrm{~g})$, phosphorus $(0.35 \pm 0.10 \mathrm{~g} / 100$ $\mathrm{g})$, and sulphur $(0.75 \pm 0.15 \mathrm{~g} / 100 \mathrm{~g})$ content. In addition, accessions of this cluster presented the lowest values for morphological traits including seed area (125.35 \pm 16.88$)$, seed perimeter $(4.44 \pm 0.33)$, seed width $(1.18 \pm 0.11)$, seed length $(1.33 \pm 0.08)$ and seed weight. Cluster 2 consisted of $17.24 \%$ of spider plant accessions. The seeds had higher oxygen $(38.58 \pm 1.16)$ and potassium $(1.72 \pm$ 0.61 ) content. In contrast to Cluster 1 , the seeds of accessions in Cluster 2 had highest values for all morphological traits including seed area (193.57 \pm 23.9$)$, seed perimeter $(5.61 \pm 0.44)$, seed width $(1.50 \pm 0.15)$, seed length $(1.61 \pm 0.09)$ and 10 -seed weight (13.33 \pm 1.13$)$. In contrast to Clusters 1 and 2, Cluster 3 grouped 27.58\% of accessions with higher carbon $(59.95 \pm 1.93)$ and calcium $(1.30 \pm 0.33)$ content. Cluster 3 was also composed of accessions with higher seed perimeter (5.36 \pm $0.37)$ and seed width $(1.38 \pm 0.07)$. No significant differences were observed among clusters regarding the seed germination percentage, although accessions in Cluster 1 exhibited relatively 16\% higher values (73.78 \pm 27.93$)$.

The results of the Hierarchical Clusters Analysis (HCA) were illustrated with Fig. 8, which also gathered accessions into three clusters (A, B and C) with the composition of each cluster slightly different from the PCA clusters. The analysis of the dendrogram revealed that accessions were partially grouped based on their geographical origin and germination potential. Cluster A was composed of Asian accessions only with high germination percentage $(93.75 \pm 6.95)$, while Cluster B consisted mainly of West African accessions with higher seed size but also included one accession from East African and one from South Africa. Cluster $C$ was composed of East African accessions (6), west African accessions (4), south African accession (1) and Asian accession (1). Analysis of variance based on the dendrogram classification did not show any differences between the three clusters with regards to mineral elements (Supplementary file 2).

Table 2 Pearson correlation analysis between size, germination parameters and mineral content of Gynandropsis gynandra seeds

\begin{tabular}{|c|c|c|c|c|c|c|}
\hline Variables & $\mathrm{Mg}$ & P & S & $\mathrm{Ca}$ & MGT & \%germination \\
\hline Seed area & $-0.52^{* * *}$ & $-0.47^{*}$ & $-0.26^{\mathrm{ns}}$ & $0.33^{\mathrm{ns}}$ & $-0.16^{\mathrm{ns}}$ & $-0.20^{\text {ns }}$ \\
\hline Seed perimeter & $-0.58^{* * *}$ & $-0.37^{*}$ & $-0.17^{\mathrm{ns}}$ & $0.32^{\mathrm{ns}}$ & $-0.32^{\mathrm{ns}}$ & $-0.19^{\text {ns }}$ \\
\hline Seed width & $-0.47^{*}$ & $-0.45^{*}$ & $-0.20^{\mathrm{ns}}$ & $0.3^{\text {ns }}$ & $-0.17^{\mathrm{ns}}$ & $-0.26^{\mathrm{ns}}$ \\
\hline Seed length & $-0.53^{* * *}$ & $-0.43^{*}$ & $-0.24^{\mathrm{ns}}$ & $0.34^{\mathrm{ns}}$ & $-0.18^{\mathrm{ns}}$ & $-0.14^{\mathrm{ns}}$ \\
\hline 10-Seed weight & $-0.58^{* * *}$ & $-0.52^{* * *}$ & $-0.53^{* * *}$ & $0.47^{*}$ & $0.13^{\mathrm{ns}}$ & $-0.23^{\text {ns }}$ \\
\hline MGT & $-0.29^{\mathrm{ns}}$ & $-0.44^{*}$ & $-0.49 *$ & $0.11^{\mathrm{ns}}$ & 1.00 & $0.38^{\mathrm{ns}}$ \\
\hline$\%$ germination & $-0.19^{\mathrm{ns}}$ & $-0.06^{\mathrm{ns}}$ & $0.00^{\mathrm{ns}}$ & $-0.10^{\mathrm{ns}}$ & $0.38^{\mathrm{ns}}$ & 1.00 \\
\hline
\end{tabular}

*** $p<0.001$, ns non-significant, Mg Magnesium, $P$ Phosphorus, $S$ Sulphur, Ca Calcium, MGT Mean germination time, \%germination = germination percentage 


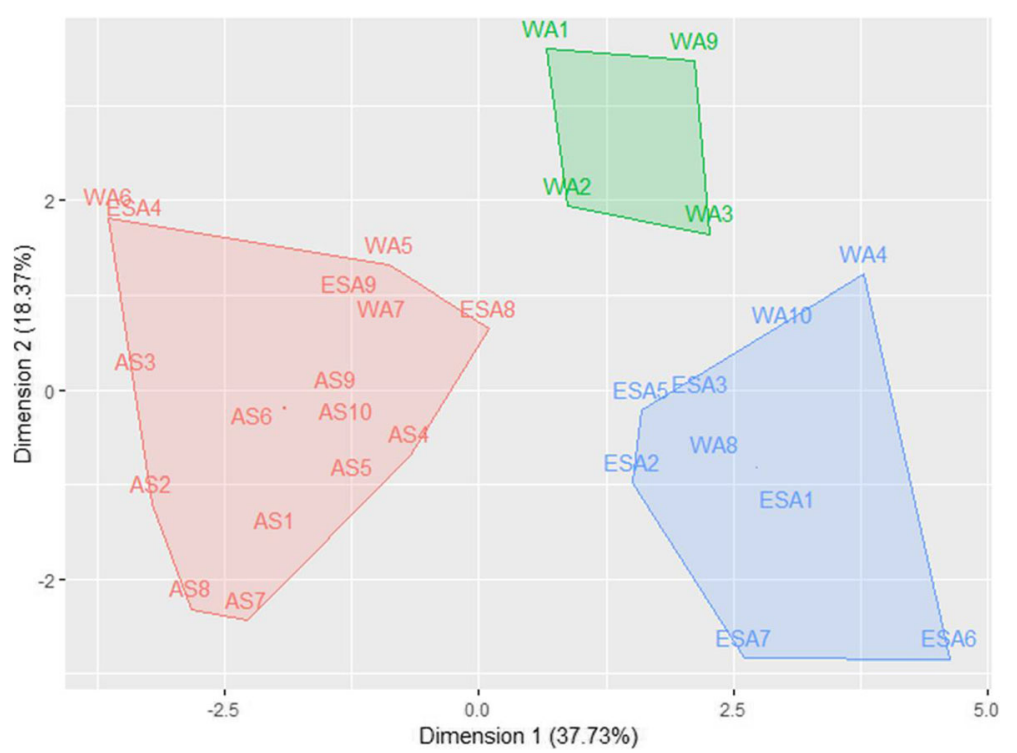

Fig. 7 Clustering of 29 Gynandropsis gynandra accessions based on seed morphology, mineral content and germination: Cluster 1 (red); Cluster 2 (blue) and Cluster 3 (green)

\section{Discussion}

The morphological traits of the seeds are relevant for taxonomic identification of plant species and the assessment of the existing genetic diversity within crop species $[26,27]$. This study investigated seed morphology, mineral composition and germination potential of 29

Table 3 Correlation between variables and the three first principal components based on seed mineral content, seed size and weight, and seed germination parameters

\begin{tabular}{lllll}
\hline Variables & Unit & \multicolumn{3}{l}{ Principal Components } \\
\cline { 4 - 6 } & & 1 & 2 & 3 \\
\hline Carbon & $\mathrm{g} / 100 \mathrm{~g}$ & 0.27 & $-\mathbf{0 . 8 0}$ & 0.43 \\
Oxygen & $\mathrm{g} / 100 \mathrm{~g}$ & -0.28 & $\mathbf{0 . 6 7}$ & -0.57 \\
Magnesium & $\mathrm{g} / 100 \mathrm{~g}$ & $\mathbf{- 0 . 7 8}$ & 0.36 & 0.21 \\
Aluminium & $\mathrm{g} / 100 \mathrm{~g}$ & 0.24 & -0.19 & $\mathbf{0 . 5 5}$ \\
Phosphorus & $\mathrm{g} / 100 \mathrm{~g}$ & $\mathbf{- 0 . 6 6}$ & 0.23 & 0.45 \\
Sulphur & $\mathrm{g} / 100 \mathrm{~g}$ & -0.53 & 0.26 & $\mathbf{0 . 6 0}$ \\
Potassium & $\mathrm{g} / 100 \mathrm{~g}$ & -0.05 & $\mathbf{0 . 5 0}$ & -0.11 \\
Calcium & $\mathrm{g} / 100 \mathrm{~g}$ & $\mathbf{0 . 5 7}$ & -0.23 & -0.14 \\
Seed area & $\mathrm{mm}$ & $\mathbf{0 . 9 0}$ & 0.35 & 0.08 \\
Seed Perimeter & $\mathrm{mm}$ & $\mathbf{0 . 8 7}$ & 0.18 & 0.38 \\
Seed width & $\mathrm{mm}$ & $\mathbf{0 . 8 5}$ & 0.38 & 0.09 \\
Seed length & $\mathrm{mm}$ & $\mathbf{0 . 8 8}$ & 0.23 & -0.18 \\
10-Seed weight & $\mathrm{mg}$ & $\mathbf{0 . 8 5}$ & 0.23 & -0.18 \\
Mean Germination Time & $\mathrm{day}$ & -0.11 & $\mathbf{0 . 5 5}$ & 0.50 \\
Percentage of germination & $\%$ & -0.12 & $-\mathbf{0 . 5 9}$ & $-0.18-$ \\
\hline
\end{tabular}

Significant values are indicated in bold.
Gynandropsis gynandra accessions from West Africa, East-southern Africa and Asia.

The study established the presence of eight (8) mineral elements, including carbon $(\mathrm{C})$, oxygen $(\mathrm{O})$, magnesium $(\mathrm{Mg})$, aluminium $(\mathrm{Al})$, phosphorus $(\mathrm{P})$, sulphur $(\mathrm{S})$, potassium (K) and calcium (Ca) in the seeds of G. gynandra accessions. One hundred gram (100 g) of dry mature seeds of G. gynandra contain on average $58 \mathrm{~g}$ of carbon, $38.04 \mathrm{~g}$ of oxygen, $0.30 \mathrm{~g}$ of magnesium, $0.20 \mathrm{~g}$ of aluminium, $0.30 \mathrm{~g}$ of phosphorus, $0.69 \mathrm{~g}$ of sulphur, $1.05 \mathrm{~g}$ of potassium and $0.92 \mathrm{~g}$ of calcium. These amounts are generally higher compared to those in Amaranth grain which contains calcium (0.0783 to $1.0046 \mathrm{~g})$, iron (0.00361 to $0.02251 \mathrm{~g})$, magnesium (0.04431 to 0.09738 g), potassium ( 0.2678 to $0.4736 \mathrm{~g})$ and zinc $(0.00053$ to $0.00123 \mathrm{~g}$ ) [28]. We observed, however, that the germination ability of the species was not correlated to any of the mineral elements identified in the seed. The function of those mineral elements can be further investigated in

Table 4 Results of the pairwise analysis of similarity among clusters

\begin{tabular}{|c|c|c|c|}
\hline \multicolumn{4}{|c|}{ Overall test } \\
\hline \multicolumn{4}{|c|}{ Overall $\mathrm{R}^{\mathrm{a}}=0.5^{* * *}$} \\
\hline Clusters & 1 & 2 & 3 \\
\hline 1 & 0 & & \\
\hline 2 & $0.74^{* * *}$ & 0 & \\
\hline 3 & $0.5^{* * *}$ & $0.47^{\text {ns }}$ & 0 \\
\hline
\end{tabular}
0.001 , ns non-significant 
Table 5 Description of clusters of Gynandropsis gynandra accessions based on the PCA results

\begin{tabular}{|c|c|c|c|c|}
\hline \multirow[t]{2}{*}{ Variables } & \multirow{2}{*}{$\begin{array}{l}\text { Cluster } 1 \\
N=16\end{array}$} & \multirow{2}{*}{$\begin{array}{l}\text { Cluster } 2 \\
N=5\end{array}$} & \multirow{2}{*}{$\begin{array}{l}\text { Cluster } 3 \\
N=8\end{array}$} & \multirow[t]{2}{*}{ F value } \\
\hline & & & & \\
\hline Carbon (g/100g) & $58.26 \pm 1.07^{b}$ & $56.95 \pm 0.76^{b}$ & $59.95 \pm 1.93^{\mathrm{a}}$ & 0.001 \\
\hline Oxygen (g/100g) & $38.30 \pm 1.02^{\mathrm{a}}$ & $38.99 \pm 0.76^{\mathrm{a}}$ & $36.91 \pm 2.01^{b}$ & 0.021 \\
\hline Magnesium (g/100g) & $0.36 \pm 0.07^{\mathrm{a}}$ & $0.28 \pm 0.08^{b}$ & $0.20 \pm 0.05^{c}$ & $p<0.001$ \\
\hline Aluminium (g/100g) & $0.16 \pm 0.15$ & $0.19 \pm 0.16$ & $0.29 \pm 0.23$ & 0.211 \\
\hline Phosphorus (g/100g) & $0.35 \pm 0.10^{\mathrm{a}}$ & $0.2 \pm 0.1^{\mathrm{ab}}$ & $0.22 \pm 0.08^{\mathrm{b}}$ & 0.008 \\
\hline Sulphur (g/100g) & $0.75 \pm 0.15^{\mathrm{a}}$ & $0.74 \pm 0.09^{a}$ & $0.53 \pm 0.17^{b}$ & 0.006 \\
\hline Potassium (g/100g) & $1.06 \pm 0.47^{b}$ & $1.78 \pm 0.67^{\mathrm{a}}$ & $0.59 \pm 0.68^{b}$ & 0.004 \\
\hline Calcium (g/100g) & $0.76 \pm 0.24^{b}$ & $0.82 \pm 0.27^{b}$ & $1.30 \pm 0.33^{\mathrm{a}}$ & $p<0.001$ \\
\hline Seed area $\left(\mathrm{mm}^{2}\right)$ & $125.35 \pm 16.88^{c}$ & $193.57 \pm 23.9^{a}$ & $169.97 \pm 19.7^{\mathrm{b}}$ & $p<0.001$ \\
\hline Seed perimeter (mm) & $4.44 \pm 0.33^{b}$ & $5.61 \pm 0.44^{a}$ & $5.36 \pm 0.37^{\mathrm{a}}$ & $p<0.001$ \\
\hline Seed width (mm) & $1.18 \pm 0.11^{b}$ & $1.50 \pm 0.15^{\mathrm{a}}$ & $1.38 \pm 0.07^{\mathrm{a}}$ & $p<0.001$ \\
\hline Seed length (mm) & $1.33 \pm 0.08^{c}$ & $1.61 \pm 0.09^{\mathrm{a}}$ & $1.54 \pm 0.12^{b}$ & $p<0.001$ \\
\hline 10-seed weight (mg) & $8.16 \pm 1.78^{b}$ & $13.33 \pm 1.13^{\mathrm{a}}$ & $13.17 \pm 2.3^{\mathrm{a}}$ & $p<0.001$ \\
\hline Mean germination time (day) & $4.33 \pm 0.2$ & $4.43 \pm 0.27$ & $4.26 \pm 0.14$ & 0.316 \\
\hline Percentage of germination (\%) & $73.78 \pm 27.93$ & $53.68 \pm 29.28$ & $57.49 \pm 28.27$ & 0.254 \\
\hline
\end{tabular}

Values in bold indicate the cluster in which each variable was high. $N=$ number of accessions. Letters $\mathrm{a}, \mathrm{b}$, and $\mathrm{c}$ indicate post-hoc comparisons among clusters.

relation with the pools of unbound metabolites and solutes produced by the degradation of storage reserves during the embryo growth and the radicle protrusion [29]. More so, further investigation could focus on the analysis of the oil, amino acid, starch or oligosaccharides profile of the seeds to complement the mineral elements content. For instance, the Kew Seed Information Database (https://data.kew.org/sid) mentioned values of
$25.5 \%$ oil content and $18.5 \%$ protein content for the species. However, we assume that using different accessions would give different results with the differences observed across regions.

Morphological traits including seed area, seed perimeter, seed length, seed width and 10-seed weight were significantly different among accessions. The results also showed significant differences among the accessions

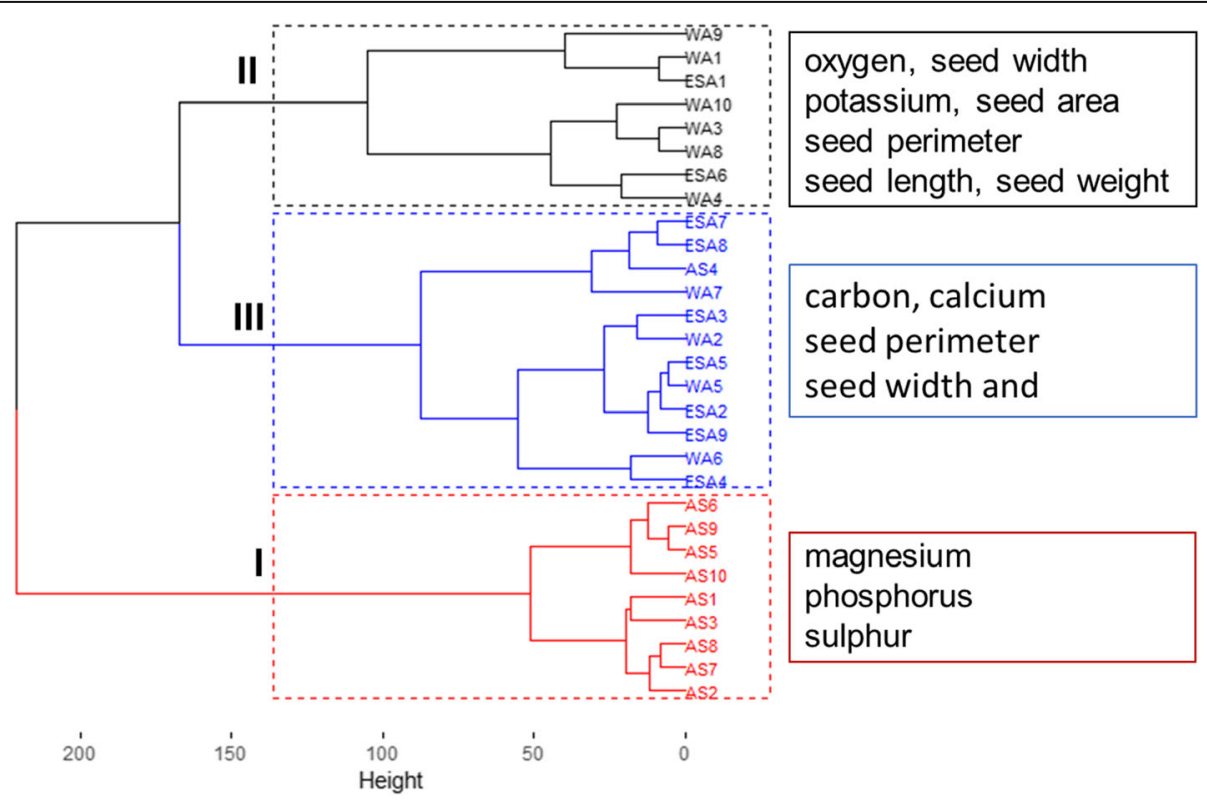

Fig. 8 Dendrogram of 29 accessions of Gynandropsis gynandra from WA: West Africa, EA: East Africa, SA: South Africa and AS: Asia based on seed morphology, germination and mineral composition with the discriminant traits of each cluster with each cluster higher discriminant traits 
with respect to germination percentage and the mean germination time. In addition, the coefficient of variation was high for the germination percentage, thus suggesting the existence of phenotypic diversity among accessions. Initial seed viability was high for the randomly selected four accessions used as control. However, the Asian accessions showed higher viability percentage $(95 \%)$ than the accessions from West Africa (92.5\%) and East Africa $(<83 \%)$. This confirmed the results of the germination test which followed the same trend. However, we observed a huge difference between the viability percentage of seeds from East Africa and their germination percentages (up to $70 \%$ difference). We concluded that the difference observed in germination percentages of Gynandropsis gynandra accessions from Asia, East Africa and West African was due to dormancy. Various dormancy breaking methods can be further investigated to confirm our findings.

Baskin, Baskin [30] explained that in general the number of plant species that may acquire dormancy tend to increase with geographical distance from the equator and correlates with the occurrence of seasons. Dormancy variation can also be found within plant species. In Arabidopsis thaliana, it has been observed that accessions from southern Europe and parts of Asia show a tendency for higher seed dormancy levels compared with accessions from northern Europe [27]. In our case, spider plant accessions from Asia showed lower dormancy levels compared with accessions from Africa. This result complemented the explanation provided by Baskin, Baskin [30].

The identification of Gynandropsis gynandra specific seed dormancy regulators can significantly enhance the germination capacity of the species and its adoption. Seed germination and dormancy regulation in plants is controlled by several factors including proteins, plant hormones (abscissic and gibberellic acid), chromatin related factors (e.g. methylation, acetylation, histone), related genes (maturing genes, hormonal and epigenetics regulating genes) [31, 32]. Future research could investigate hormonal signalling during seed germination and seed biology. Genetic and molecular dormancy investigation in the species could also be performed as realized in Arabidiospsis thalania [33, 34] to study the gene expression profiles in different accessions of Gynandropsis gynandra based on the observed variation about dormancy.

Genetic variation has been studied in many species by crossing genotypes with different dormancy levels, followed by the analysis of their progeny and parallel selection for seed dormancy [33, 35, 36]. The analysis of association patterns among morphological seed traits, mineral elements and germination parameters revealed significant negative correlations between seed size (i.e. area, length, perimeter, width), 10-seed weight and mean germination time with phosphorus content. Seeds with high phosphorus content showed a reduced mean germination time, thus suggesting that phosphorus plays an important role during germination. Based on the results in this study, the hypothesis that larger seeds germinate faster/ better than smaller seeds is rejected because no correlation was observed between seed size, germination percentage and mean germination time. However, even though no correlations between seed size and germination percentage were observed, the Asian accessions which had the smallest seed size germinated better than those from East and West Africa. Similar results were reported in pea (Pisum sativum L.) where seeds with low seed weight showed higher germination percentage than those with higher seed weight [37]. In this study, Gynandropsis gynandra accessions from Asia had smaller seed size and weight and also showed the highest germination percentage. These findings imply that seed dormancy and bottlenecks in seed germination of Gynandropsis gynandra could be improved through crosses among the best accessions based on seed size and germination percentage.

Phenotypic diversity assessment is important to depict the extent of genetic diversity within crop species for the development and deployment of improved varieties with farmers' desired traits [38, 39]. Our results showed three clusters of accessions highly discriminated by seed parameters including seed area, seed length, seed perimeter, seed width, 10-seed weight, mean germination time, magnesium, phosphorus, sulphur, calcium, carbon, oxygen, and potassium. The clustering was also partially explained by the geographical origin of accessions as revealed by Sogbohossou et al. [20] that focused on plant morphology and leaf nutrients content. For example, the authors found that Asian accessions were characterized by short plants with broad leaves [20] whereas in our case Asian accessions are characterized by small seed size, high phosphorus content and better germination percentage. Further studies could investigate the correlation between morphological characteristics of the seed and the leaf yield of Gynandropsis gynandra to develop a selection index for higher yielding leaf accessions based on the morphological traits of the seeds. Moreover, based on our results, accessions with extreme values can be used to develop mapping populations for seed related traits including fatty acid, protein, and gibberellic acid content. Seed traits could be incorporated into breeding programmes for an effective improvement of Gynandropsis gynandra as reported by Mohammed et al. [40] on Bambara groundnut (Vigna subterranea [L.] Verdc.). Finally, the phenotypic diversity observed among G. gynandra accessions for seed metric parameters, seed germination and mineral content can be used to 
improve the germination capacity of the species as well as the yield of the species.

\section{Conclusion}

This study has generated useful information about the internal and external seed morphology as well as mineral composition of Gynandropsis gynandra seeds. Seed mineral composition differed significantly among different accessions except for aluminium. The relatively highlevel of dissimilarity observed among clusters, and especially among accessions from different geographical areas provides a basis for the identification of desirable parents. This can be used to create segregating populations and better possibilities for genetic improvement of the crop. The diversity observed among spider plant accessions using seed attributes was also an indicator that a systematic selection of spider plant accessions into homogenous groups of seeds could be done for an effective breeding to boost seed quality, crop productivity and nutritional security.

\section{Methods}

\section{Plant materials}

Twenty-nine (29) accessions from three different geographic regions, namely, West Africa, East-Southern Africa and Asia were used in the study (Table 6). Seeds from these accessions were harvested in 2017 from an experimental site at the Faculty of the Agronomic Sciences (FSA) of the University of Abomey Calavi in Benin and stored for 15 months before the start of this experiment. The species was grown during the rainy season from April to July 2017 during which the temperature varied between $25.6{ }^{\circ} \mathrm{C}$ and $28^{\circ} \mathrm{C}$, the average rainfall varied between 137 and $356 \mathrm{~mm}$ monthly and the relative humidity oscillated between 72.5 and $82.5 \%$ (https:// www.weather atlas.com/en/benin/cotonou-climate). We harvested three plants per accession.

\section{Seed morphology traits and mineral composition}

Morphological and mineral element studies were performed at the Microscopic Microanalysis Unit (MMU) and the Phytopathology Laboratory of the University of KwaZulu-Natal, College of Agriculture, Engineering and Science. Scanning Electron Microscope (SEM) images were obtained with Zeiss Microscopy (EVO/LS15) of the Microscopic Microanalysis Unit (MMU). Seed samples were mounted on copper stubs on a double sided adhesive carbon tape and placed at different positions to facilitate observation. SEM images of three seeds per accessions were used to determine their dimension (images analysis). Fractured seeds (longitudinally and vertically) were used to study the seed anatomy. To complement seed description, the mineral elements analysis of seeds was done using the Integrated Energy
Dispersive Spectroscopy Solution (EDS) of the Zeiss Microscopy (EVO/LS15).

To further describe the internal structure of the seeds, observations were made using a Binocular zoom stereo microscope (Carl Zeiss Stemi SV6) equipped with an Electronic Light source (Schott KL 1500) and with a digital microscope camera.

The imaging analysis was performed on individual seeds using the digital image analysis software (AnalysisSIS) at the Microscopic Microanalysis Unit. The system was calibrated to millimeters under 100x magnification and $200 \mu \mathrm{m}$ scale before the measurements. The variables measured on imported SEM images included: 1) Seed width (SW): the distance between two points stretching from the base of the embryo axis to the tip of the endosperm of the seed (Fig. $1 \mathrm{~b}$ in green); 2) Seed length (SL): the length of the line drawn across the widest section of the seed (Fig. $1 \mathrm{~b}$ in red); 3) Seed area (A) and perimeter $(\mathrm{Pe})$ were directly obtained after drawing a circle around the seed touching all edges.

The 10-seed weight was recorded using the average weight of samples of 10 seeds randomly chosen and weighed using a precision balance Ohaus ${ }^{\circ}$ Pioneer $^{\text {tm }}$ Plus analytical balance Model PA114C, AC/DC input $230 \mathrm{~V}$ $\mathrm{AC}$, universal plug set measuring up to four decimals. The 10-seed weight was duplicated four times for each accession.

The germination capacity of the seeds was investigated using 50 seeds in a petri dish and placing them in an incubator at a temperature of $30^{\circ} \mathrm{C}$ under dark conditions. Each treatment (accession) was replicated 4 times. The number of newly germinating seeds was counted each day for seven days and used to calculate the mean germination time (eq. 1) and the percentage germination.

$$
M G T=(\Sigma \text { nidi }) / \Sigma \mathrm{N})(1)
$$

where $n i=$ the number of germinated seeds at day $i, d i=$ incubation period in days, and $N=$ number of germinated seeds in test.

The tetrazolium viability test, described by the International Seed Testing Association (ISTA) book [41], was done to ensure that the seeds were viable before conducting germination tests. However, due to the limited number of available seeds, a sample of four accessions from Asia, East and West Africa (including TOT 8887, TOT5499, ODS-15-020 and ELG 19078) were used with four replicates of ten seeds per accessions. Seeds were imbibed in distilled water for $24 \mathrm{~h}$ at $20^{\circ} \mathrm{C}$ and cut into two parts before $1.0 \%$ of 2,3,5 triphenyl tetrazolium chloride solution (TZ) were added. After $24 \mathrm{~h}$ of incubation at $30^{\circ} \mathrm{C}$ the number of viable and non-viable seeds were identified by the staining of the embryo and 
Table 6 Origin and institutional provenance of accessions used for seed morphology traits and mineral composition in Gynandropsis gynandra. KENRIK: Kenya Resource Center for Indigenous Knowledge; WVC: World Vegetable Center; GBioS: Laboratory of Genetics, Horticulture and Seed Science

\begin{tabular}{|c|c|c|c|c|}
\hline Code & Accession & Institution & Origin & Region \\
\hline ESA1 & BAR 1807B & KENRIK & Kenya & East-Southern Africa \\
\hline ESA2 & ELG 19/07A & KENRIK & Kenya & East-Southern Africa \\
\hline ESA3 & $\mathrm{HBY} / 2307 \mathrm{~b}$ & KENRIK & Kenya & East-Southern Africa \\
\hline ESA4 & KF-07 & KENRIK & Kenya & East-Southern Africa \\
\hline ESA5 & KSI 2407A & KENRIK & Kenya & East-Southern Africa \\
\hline ESA6 & TOT6439 & WVC & Zambia & East-Southern Africa \\
\hline ESA7 & TOT8887 & WV & Uganda & East-Southern Africa \\
\hline ESA8 & ТОТ8926 & WVC & Kenya & East-Southern Africa \\
\hline ESA9 & ТОT8931 & WVC & South Africa & East-Southern Africa \\
\hline WA1 & ODS-15-013 & GBioS & Benin & West Africa \\
\hline WA2 & ODS-15-019 & GBioS & Benin & West Africa \\
\hline WA3 & ODS-15-020 & GBios & Benin & West Africa \\
\hline WA4 & ODS-15-044 & GBioS & Benin & West Africa \\
\hline WA5 & ODS-15-045 & GBios & Togo & West Africa \\
\hline WA6 & ODS-15-053 & GBioS & Togo & West Africa \\
\hline WA7 & ODS-15-061 & GBios & Togo & west Africa \\
\hline WA8 & ODS-15-100 & GBioS & Togo & West Africa \\
\hline WA9 & ODS-15-115 & GBios & Ghana & West Africa \\
\hline WA10 & ODS-15-121 & GBioS & Ghana & West Africa \\
\hline AS1 & TOT1048 & WVC & Thailand & Asia \\
\hline AS2 & ТОТ3527 & WVC & Lao People's Democratic Republic & Asia \\
\hline AS3 & TOT3536 & WVC & Lao People's Democratic Republic & Asia \\
\hline AS4 & TOT4976 & WVC & Thailand & Asia \\
\hline AS5 & TOT5799 & WVC & Thailand & Asia \\
\hline AS6 & TOT7196 & WVC & Malaysia & Asia \\
\hline AS7 & TOT7198 & WVC & Malaysia & Asia \\
\hline AS8 & TOT7200SC & WVC & Malaysia & Asia \\
\hline AS9 & TOT7486 & WV & Lao People's Democratic Republic & Asia \\
\hline AS10 & TOT7505 & WVC & Lao People's Democratic Republic & Asia \\
\hline
\end{tabular}

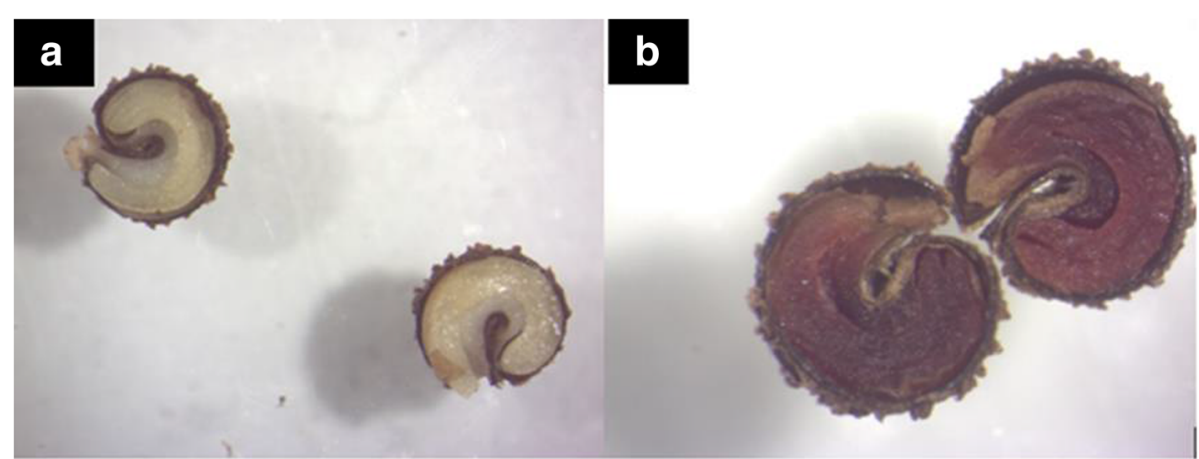

Fig. 9 Light microscopy images of spider plant seed cross section showing how its stain with a tetrazolium solution; $\mathbf{a}$ : before tetrazolium test $\mathbf{b}$ : Viable seed after tetrazolium test (scale $200 \mu \mathrm{m}$ ) 
counted under a light microscope at the Plant Pathology laboratory of the University of KwaZulu-Natal (Fig. 9).

\section{Data analysis}

Descriptive analysis was conducted to show trends in morphological traits, germination and mineral elements. Analysis of variance (ANOVA) was carried out on all quantitative variables to describe the variation among accessions except for the mean germination time and percentage of germination that were compared using a generalised linear model with quasi-poisson error structure. The Kruskal-Wallis tests was used as appropriate to compare the mean germination time and the percentage of germination of accessions from different regions. Means were separated using Least Significant Difference (LSD 5\%) for seed morphological trait and mineral element contents. Pearson correlation analysis was done to show the linear correlation among morphological traits, mineral content and germination parameters. In addition, principal components analysis (PCA) and hierarchical cluster analysis (HCA) were performed to group the 29 accessions into different clusters using seed morphological traits, germination parameters and mineral element contents with the R package "FactoMiner" [42]. A dendrogram was generated using the function "hclust" of the R package "vegan" [43] to analyse the relationship among the accessions. All the data were analyzed using R software version 3.5.1 [44].

\section{Supplementary information}

Supplementary information accompanies this paper at https://doi.org/10. 1186/s12870-020-02364-W.

Additional file 1. The file presents the list of accessions included in the study, their geographic origins and codification name. This file included also the mean and standard deviation for all morphological traits, mineral element contents and germination parameters of all Gynandropsis gynandra accessions used in the study.

Additional file 2. The file presents the description of each cluster based on the dendrogram results

\section{Abbreviations}

Al: Aluminium; ANOVA: Analysis of variance; B: Boron; C: Carbon; Ca: Calcium; Co: Cobalt; Cu: Copper; EDS: Energy Dispersive Spectroscopy;

GLM: Generalized Linear Model; HCA: Hierarchical Clusters Analysis; ISTA: International Seed Testing Association; K: Potassium; LSD: Least Significant Difference; Mg: Magnesium; MGT: Mean Germination Time; MMU: Microscopic Microanalysis Unit; Mo: Molybdenum; O: Oxygen; P: Phosphorus; PCA: Principal Components Analysis; S: Sulphur; Se: Selenium; SEM: Scanning Electron Microscopy; Zn: Zinc

\section{Acknowledgments}

The authors are grateful to Carlos Houdegbe for his assistance during data collection and Félicien Akohoue for his useful inputs during data analysis. The authors would also like to thank technicians at the microscopic micro analysis unit (MMU) of the University of KwaZulu-Natal for assistance with the scanning electron microscope (SEM).

\section{Authors' contributions}

$J S B, A O, J S$, and EGA-D were responsible for the conception, design, and supervision of the overall study and interpretation of data. JSB was involved in the experimental design, acquisition of data, analysis and interpretation of the data. EODS, JS and EGA-D critically revised the manuscript. All authors read and approved the final version of the manuscript.

\section{Funding}

Ms. Jelila Blalogoe, from the University of Abomey-Calavi in Republic of Benin, was a scholar of the "Intra-Africa Academic Mobility Scheme" under the project grant number 2016-2988 on "Enhancing training and research mobility for novel crops breeding in Africa (MoBreed)" funded by the Education, Audiovisual and Culture Executive Agency (EACEA) of the European Commission. The project provided a scholarship for twelve months' research mobility and a partial research grant to the first Author to complete an MSC degree at the University of KwaZulu Natal (South Africa).

\section{Availability of data and materials}

All data generated or analysed in this study are included within the article or supplementary materials. The raw datasets and $\mathrm{R}$ scripts generated during the current study are available from the corresponding author on reasonable request. The seeds used in this study can be requested from the Laboratory of Genetics, Horticulture and Seed Science, Faculty of Agronomic Sciences, University of Abomey-Calavi, BP 2549, Abomey-Calavi, Republic of Benin or from the Gene bank of the Biosystematics Group, Wageningen University, Droevendaalsesteeg 1, 6708 PB Wageningen, The Netherlands using same accessions names.

Ethics approval and consent to participate

Not applicable.

\section{Consent for publication}

Not applicable.

\section{Competing interests}

The authors declare that they have no competing interests.

\section{Author details}

${ }^{1}$ Laboratory of Genetics, Horticulture and Seed Science, Faculty of Agronomic Sciences, University of Abomey-Calavi, BP 526 Abomey-Calavi, Republic of Benin. 'Discipline of Plant Breeding, School of Agricultural, Earth and Environmental Sciences, University of KwaZulu-Natal, Private Bag X01, Scottsville 3209, Pietermaritzburg, Republic of South Africa. ${ }^{3}$ Crop Science, School of Agricultural, Earth and Environmental Sciences, University of KwaZulu-Natal, Pietermaritzburg, Republic of South Africa. ${ }^{4}$ Biosystematics Group, Wageningen University, Postbus 647 6700AP, Wageningen, The Netherlands.

Received: 28 May 2019 Accepted: 26 March 2020

Published online: 15 April 2020

\section{References}

1. Ambika S, Manonmani V, Somasundaram G. Review on effect of seed size on seedling vigour and seed yield. Res J Seed Sci. 2014;7(2):31-8.

2. Khan F, Hakeem KR. Genetic modification of crop plants: issues and challenges. In: K.R. Hakeem (ed.), Crop Production and Global Environmental Issues, Vol 10: Springer; Switzerland, 2015. p. 369-384.

3. Eggert $K$, von Wirén N. Dynamics and partitioning of the ionome in seeds and germinating seedlings of winter oilseed rape. Metallomics. 2013;5(9): 1316-25.

4. Marcos Filho J. Seed vigor testing: an overview of the past, present and future perspective. Sci Agric. 2015;72(4):363-74.

5. Kaydan D, Yagmur M. Germination, seedling growth and relative water content of shoot in different seed sizes of triticale under osmotic stress of water and $\mathrm{NaCl}$. Afr J Biotechnol. 2008;7(16):2862-8.

6. Adebisi M, Kehinde T, Salau A, Okesola L, Porbeni J, Esuruoso A, Oyekale K. Influence of different seed size fractions on seed germination, seedling emergence and seed yield characters in tropical soybean (Glycine max L. Merrill). J Int Pharmeutical Ressour. 2013;8:26-33.

7. Gunaga RP, Vasudeva R. Influence of seed size on germination and seedling growth in Mammea suriga. Karnataka J Agri Sci. 2011; 24(3):415-16. 
8. Wyllie-Echeverria S, Cox P, Churchill A, Brotherson J, Wyllie-Echeverria T. Seed size variation within Zostera marina L.(Zosteraceae). Bot J Linn Soc. 2003;142(3):281-8.

9. Balkaya A, Odabas MS. Determination of the seed characteristics in some significant snap bean varieties grown in Samsun, Turkey. Pak J Biol Sci. 2002; 5(4):382-7..

10. Cerdà A, Garcia-Fayos P. The influence of seed size and shape on their removal by water erosion. Catena. 2002;48(4):293-301.

11. Mandal SM, Chakraborty D, Gupta K. Seed size variation: influence on germination and subsequent seedling performance in Hyptis suaveolens (Lamiaceae). Res J Seed Sci. 2008;1(1):26-33.

12. Gholami A, Sharafi S, Sharafi A, Ghasemi S. Germination of different seed size of pinto bean cultivars as affected by salinity and drought stress. Food Agric Environ. 2009;7(2):555-8.

13. Menaka C, Balamurugan P. Seed grading techniques in Amaranthus Cv. CO5. Plant Arch. 2008:8(2):729-31.

14. Tyler G, Zohlen A. Plant seeds as mineral nutrient resource for seedlings-a comparison of plants from calcareous and silicate soils. Ann Bot. 1998;81(3): 455-9.

15. Zhu Y, Smith S. Seed phosphorus (P) content affects growth, and $P$ uptake of wheat plants and their association with arbuscular mycorrhizal (AM) fungi. Plant Soil. 2001;231(1):105-12.

16. Bolland M, Paynter B. Increasing phosphorus concentration in seed of annual pasture legume species increases herbage and seed yields. Plant Soil. 1990;125(2):197-205.

17. Oluoch MO, Pichop GN, Silué D, Abukutsa-Onyango MO, Diouf M. Production and harvesting systems for African indegenous vegetables. In: Drescher A, editor. Shackleton MWP. London: African Indigenous Vegetables in Urban Agriculture. Earthscan; 2009. p. 145-75.

18. Muchuweti M, Kasiamhuru A, Benhura M, Chipurura B, Amuna P, Zotor F, Parawira W. Assessment of the nutritional value of wild leafy vegetables consumed in the Buhera district of Zimbabwe: A preliminary study. In: International Symposium on Underutilized Plants for Food Security, Nutrition, Income and Sustainable Development 806; 2008. p. 323-30.

19. Omondi EO, Engels C, Nambafu G, Schreiner M, Neugart S, AbukutsaOnyango M, Winkelmann T. Nutritional compound analysis and morphological characterization of spider plant (Cleome gynandra)-an African indigenous leafy vegetable. Afr J Horticultural Sci. 2017;100:284-95.

20. Sogbohossou ED, Kortekaas D, Achigan-Dako EG, Maundu P, Stoilova T, Van Deynze A, de Vos RC, Schranz ME. Association between vitamin content, plant morphology and geographical origin in a worldwide collection of the orphan crop Gynandropsis gynandra (Cleomaceae). Planta. 2019;250(no.3): 933-47

21. Masuka A, Goss M, Mazarura U. Morphological characterization of four selected spider plant (Cleome gynandra L.) morphs from Zimbabwe and Kenya. Asian J Agri Rural Dev. 2012;2(4):646.

22. Wasonga D, Ambuko J, Chemining G, Odeny D, Crampton B. Morphological characterization and selection of spider plant (cleome Gynandra) accessions from Kenya and South Africa. Asian J Agri Sci. 2015;7(4):36-44.

23. Kwarteng A, Abogoom J, Amoah RA, Nyadanu D, Nyam C, Ghunney T, Awuah E, Ziyaaba J, Ogunsanya J, Orhin E (2018) Phenomic characterization of twenty-four accessions of spider plant (Cleome gynandra L.) the upper east region of Ghana. Sci Hortic 235:124-131. doi:https://doi.org/https://doi. org/10.1016/j.scienta.2018.02.046.

24. Wu T-h, Solberg SO, Yndgaard F, Chou Y-Y. Morphological patterns in a world collection of Cleome gynandra. Genet Res Crop Evol. 2018;65(1):271-83.

25. Iltis HH, Hall JC, Cochrane TS, Sytsma KJ. Studies in the Cleomaceae I. on the separate recognition of Capparaceae, Cleomaceae, and Brassicaceae. Ann Mo Bot Gard. 2011;98(1):28-36.

26. Adewale B, Kehinde O, Aremu C, Popoola J, Dumet D. Seed metrics for genetic and shape determinations in African yam bean [Fabaceae] (Sphenostylis stenocarpa Hochst. Ex. A. Rich.) harms. African J Plant Sci. 2010:4(4):107-15.

27. Daryono BS, Sentori MB. Variability and intraspecies classification of pumkin (cucurbita moschata (duch. Ex lam.) duch. Ex poir.) based on morphological characters. Life Sci. 2015;2(1):286-93.

28. Kachiguma NA, Mwase W, Maliro M, Damaliphetsa A. Chemical and mineral composition of Amaranth (Amaranthus L.) species collected from Central Malawi. J Food Res. 2015:4(4):92.
29. Rosental L, Nonogaki $H, A J S s r ~ F$. Activation and regulation of primary metabolism during seed germination. 2014:24(1):1-15.

30. Baskin C, Baskin J. Seeds: ecology, biogeography and evolution of dormancy and germination. 2nd. San Diego: Academic Press, Elsevier; 2014. p. $150-162$.

31. Miransari M, Smith D. Plant hormones and seed germination. Environ Exp Botany. 2014;99:110-21.

32. Née G, Xiang Y, Soppe WJ. The release of dormancy, a wake-up call for seeds to germinate. Curr Opin Plant Biol. 2017;35:8-14

33. Alonso-Blanco C, Bentsink L, Hanhart CJ, Blankestijn-de Vries H, Koornneef M. Analysis of natural allelic variation at seed dormancy loci of Arabidopsis thaliana. Genetics. 2003;164(2):711-29.

34. Bentsink L, Hanson J, Hanhart CJ, Blankestijn-de Vries H, Coltrane C, Keizer P, El-Lithy M, Alonso-Blanco C, de Andrés MT, Reymond M. Natural variation for seed dormancy in Arabidopsis is regulated by additive genetic and molecular pathways. Proc Natl Acad Sci. 2010;107(9):4264-9.

35. Lin S, Sasaki T, Yano M. Mapping quantitative trait loci controlling seed dormancy and heading date in rice, Oryza sativa L., using backcross inbred lines. Theor Appl Genetics. 1998;96(8):997-1003.

36. Wang M, Li W, Fang C, Xu F, Liu Y, Wang Z, Yang R, Zhang M, Liu S, Lu S. Parallel selection on a dormancy gene during domestication of crops from multiple families. Nat Genet. 2018:50(10):1435.

37. Peksen E, Peksen A, Bozoglu H, Gulumser A. Some seed traits and their relationships to seed germination and field emergence in pea (Pisum sativum L.). J Agron. 2004;3(4):243-6.

38. Govindaraj $M$, Vetriventhan $M$, Srinivasan $M$. Importance of genetic diversity assessment in crop plants and its recent advances: an overview of its analytical perspectives. Genetics Re Int. 2015. p. 1-14. https://doi.org/10. $1155 / 2015 / 431487$

39. Fu Y-B. Understanding crop genetic diversity under modern plant breeding. Theor Appl Genet. 2015;128(11):2131-42.

40. Mohammed M, Shimelis H, Laing M. Phenotypic characterization of diverse Bambara groundnut (Vigna subterranea [L.] Verdc.) germplasm collections through seed morphology. Genetic Res Crop Evol. 2016;63(5):889-99.

41. International Seed Testing Association. International Rules for Seed Testing. Seed Sci Tech. 2012;27(Supplement):333.

42. Lê S, Josse J, Husson F. FactoMineR: an R package for multivariate analysis. Stat Softw. 2008;25(1):1-18. https://doi.org/10.18637/jss.v025.i01.

43. Oksanen J, Blanchet FG, Kindt R, Legendre P, Minchin PR, O'hara R, Simpson GL, Solymos P, Stevens MHH, Wagner H (2013) Package 'vegan'. Community ecology package, version 2 (9). doi:https://CRAN.R-project.org/package= vegan.

44. Team RC. R: a language and environment for statistical computing. Vienna, Austria: R Foundation for Statistical Computing; 2018. Doi: https://www.Rproject.org/

\section{Publisher's Note}

Springer Nature remains neutral with regard to jurisdictional claims in published maps and institutional affiliations.

Ready to submit your research? Choose BMC and benefit from:

- fast, convenient online submission

- thorough peer review by experienced researchers in your field

- rapid publication on acceptance

- support for research data, including large and complex data types

- gold Open Access which fosters wider collaboration and increased citations

- maximum visibility for your research: over $100 \mathrm{M}$ website views per year

At $\mathrm{BMC}$, research is always in progress.

Learn more biomedcentral.com/submissions 